Williams at a certain price. This seemed to me so low that I asked them about it, when they did inform me that the reason was its occurring as a by-product. Nothing whatever was then said, however, about being "impure"; on the contrary, they inclosed two small fragments, one of which they said they sold as "pure," and the other (at half price) as "impure." The last was a light yellow-brown colour, and I never meddled with it ; of the other I purchased an ounce for trial. On finding so much silica and soda I wrote them reporting, and asking if the sample was reduced by the hyposulphite process, as Dr. Draper had mentioned the difficulty of getting a pure product in that way. They replied that hyposulphite was used, and that the "pure" sample might possibly contain soda, but they thought not silica ; the other sample might contain soda, silica, and probably iron. I wrote again pointing out that oxyhydrogen illumination was the most likely use for the product, and asking if they could not purify it further at an enhanced price, when they declined, as they state.

The difference is, that all this took place after I had purchased and tested the sample, and reported to them upon it. I inclose you copy of their price list of I886, still later, in which you will see that "zirconium oxide" still appears without qualification and $I$ also forward the original bottle and label which $I$ received from them-the latter you will perceive is "pure zirconia." The correspondence, if sent you in full, will bear out all the details above.

At the same time I would say that $\mathrm{I}$ had not the least idea of impugning in any way Messrs. Hopkin and Williams. I simply pointed out, as reference will show, the generally unsatisfactory character of samples considered commercially "pure " (one never expects ordinary purchased articles "pure" in any other sense) for one special purpose, and I much regret that their letter necessitates this correction.

LEWIS WRIGHT.

P.S.-I am sorry to add that my previous letter has not elicited any very satisfactory information, or real aid towards the desired object. I learn from Mr. Cottrell that $\mathrm{Du}$ Motay's cylinders were unquestionably more durable than any prepared since, even with the aid of Prof. Maskelyne. But I am as unable as ever to come across one, or to find exactly how the material was prepared, or what light it gave in comparison with limes.

\section{THE JUBILEE.}

II.

WE have already referred to some aspects of the Jubilee which have a special relation to science, and we shall soon have occasion to return to the subject. In the meantime we reprint from the Times an admirable passage which presents a striking confirmation of the opinions we have expressed as to the true place of science in the history of the past fifty years. The passage is from the "Jubilee Retrospect" which appeared in the Times on Tuesday last :-

"The keynote of the Victorian era is the development of scientific research, the concomitant growth of practical invention, and the expansion of industry which these have brought about. Other ages have been fruitful of profound scientific conceptions, or have been illustrated by great inventions and discoveries, but it would be difficult to point to any half-century in the history of the world in which equal progress in speculative science has been combined with anything approaching to the magnitude, variety, and importance of the applications of science to practical ends which distinguish the present reign. It is as true to-day as at any former period that nothing great can be done in pure science save by men who make the discovery of truth the sole aim of their efforts, and who prize no other reward. But it is no less true that abstract and applied science go hand in hand as they never did before, and that each owns enormous obligations to the other. For if the triumphs of the workshop have been achieved by means of the discoveries made in the laboratory, on the other hand the laboratory depends for every step of its advance upon the technical skill and hitherto unrivalled precision of the workshop. Physical science has reached a stage at which the verification of its hypotheses and the supply of new data for its specula- tions demand appliances of extraordinary excellence, and in many cases a collation of experience and experiment which nothing but the practical inventions of the age could render possible. It is doubtless to the co-ordination of the two forms of intellectual activity that we owe the rapidity of recent advance. An unprecedentedly large army of inquirers has simultaneously pushed the interrogation of nature in a thousand directions, and has attained unprecedented results. But beside them has been working an army larger, and equally keen, of men eagerly seeking to utilize for practical ends every crumb of available information, and giving to scientific ideas a concrete application which often forms the starting-point for new processes of scientific induction.

"The fundamental conceptions of the material universe entertained by educated men have been revolutionized during the last fifty years. The simple atomic theory of the older chemistry has given place to a molecular theory, which itself has undergone considerable development. The outlines of the elements which the older chemistry accepted as an ultimate analysis are melting under the gaze of the spectroscopist, who across the haze of their wavering figures catches glimpses of a simple primal matter. The evolution of matter is, however, like the evolution of living forms, a philosophical conception which must always rest rather upon the general necessities of thought than upon actual experiment. The immutability of certain forms of matter in all the conditions that we can devise or have any experience of is as absolute as the persistence of specific types in the animal or vegetable kingdom. The most refractory substances have been vaporized in the electric arc, and the most attenuated gases have assumed the solid form under the combined influence of intense cold and enormous pressure. But we have made no nearer approach to actual evidence either of material evolution or of the complexity of the socalled elements than may be inferred from certain spectroscopic observations of the sun and some experiments tending to show that in some cases we have confounded two or more very similar elements under one name. Apart, however, from these abstruse speculations, the whole tendency of physical and chemical investigation has been to bridge the gulf formerly fixed between molar and molecular motion and between chemical and mechanical force. There is an obvious interdependence between this scientific movement and the doctrine of the conservation of energy, which is one of the main philosophical achievements of the epoch under discussion. According to that doctrine, the total energy of any body or system of bodies is a quantity as absolutely fixed and as incapable of suffering either increase or diminution as the matter of which these bodies are composed. Energy, like matter, may assume an endless variety of forms; but the force put forth by the locomotive is as indestructible as the particles which compose its framework or its fuel. But to balance our account we have to take cognizance not only of the forces of impact or pressure of which we have direct experience, and conceive ourselves to have tolerably full understanding, but also of the forces of attraction and repulsion in their various forms, concerning which we as yet know absolutely nothing beyond the fact of their existence as inferred from their effects. To refer the whole complex sum of these energies to a general law, and to deal with them on fundamental physical and mathematical principles, is the aim of the physical science of to-day. Notwithstanding all superficial resemblances, it stands differentiated from the science of all past ages by the clearness with which it apprehends the nature of this quest and the unrivalled range of the analytical methods it has brought to bear. In the domain of biology the theory of evolution, first placed upon a scientific basis by the genius of Darwin, is a product of the same great movement of philosophic thought which brought forth the molecular theory of matter and the doctrine of the conservation of 
energy. The idea of evolution itself was not new, but what was new was the proof that in the vast geological changes established by the labours of Lyell and other workers in the same field, in the visible tendency to variation in existing plants and animals, and in the evidence collected by Darwin's industry and observation of the power of the struggle for existence to exercise, in given conditions, a selective and protective influence upon occasional variations, we have all the data required for the construction of a coherent theory. Evolution has now definitely taken its place as a working scientific hypothesis, not, indeed, capable of explaining all the facts of biology, but consistent with these facts and furnishing - the most that a scientific hypothesis can ever do-the means of systematizing our knowledge in preparation for a further advance. The study of embryology is already modifying profoundly the interpretation put upon the evolutionary theory, and is probably paving the way for some new generalization. Mr. Herbert Spencer's application of the theory of evolution to the facts of social order is the expression, in the sphere of human thought and action, of the intellectual movement of which Darwin made himself the exponent in the field of biology.

"But striking as is the enlargement of the intellectual horizon during the last fifty years, the imagination is more powerfully impressed by the enormous extension of the applied knowledge which vivifies and transforms old industries, invents new ones, abridges the whole mass of social labour, annihilates the obstacles of time and space, destroys the enemies of the general well-being, and endows the whole population with conveniences, comforts, and luxuries which a century ago were beyond the reach of kings. It seems as if the tree of national effort, after long putting forth scanty leaves and rare blossoms, had suddenly borne a load of fruit. Knowledge, which had long lain dormant or had led only to slow and trivial change, seems suddenly to have acquired a new significance in the minds of men, and to have taken on a new and unprecedentedly rapid development. Physical science had made great advances between the age of Elizabeth and the close of the last century ; but relays of swift horses represented at one period as at the other the most rapid attainable mode of travelling or of transmitting news. The power of steam had been practically utilized by Watt a hundred years ago, and the investigation of electrical phenomena had made great progress before the accession of Victoria, but the whole of the vast improvements in locomotion and the transmission of news which we now enjoy have been effected since that event. With the exception of one or two short lines, the whole railway system of the country is the creation of the last half-century, and its effect upon the fortunes of the nation can hardly be over-estimated. The England of to-day has, in fact, been rendered possible only by the railway system, which in turn has been fed by the industries it fostered, and depends for its very existence in the form we know upon the modern development of telegraphy and engineering. It is easy, but not particularly useful, to give statistics showing the growth of railway enterprise since George Stephenson began his task of developing steam communication. No figures can add to the impressiveness of the consideration that, whereas railways are now every where, fifty years ago they were practically nowhere. Our whole modern system of commerce has grown up around this efficient system of intercommunication, and depends absolutely upon rapid transit for its very existence. But the direct results of the application of steam to locomotion are probably trivial in comparison with its profound influence upon the social life and even the moral character of the nation. The population of the country, formerly attached to the soil on which it was born by necessities stronger than feudal custom, has been endowed with the power of easy, rapid, and comparatively cheap locomotion. For good and for evil the habits of mind belonging to an age characterized upon the whole by permanence of local relationships have given place to the habits proper to a time in which labour is nomadic, and all the relations of life in the remotest districts are profoundly affected by the attraction of distant centres of population. The immense increase of these centres, and the corresponding depopulation of rural districts, is one of the most obvious results, not, indeed, of railways alone, but of that industrial revolution in which they have played a central and indispensable part. That revolution may be defined as a great and sustained movement in the direction of economizing and organizing labour. Railways have powerfully promoted economy by reducing to a fraction of its former amount the time spent in the transport of goods and workmen, and they have no less powerfully promoted organization by equalizing conditions and combining a thousand isolated stores of industrial energy into one central reservoir. Nor must we leave out of sight the enormous effect they have produced by facilitating the transmission of correspondence and news. While the railways were yet in their cradle they were utilized for the carriage of the mails, but the whole postal system was so chaotic and inefficient that the public could have reaped but little advantage save for the drastic reforms advocated by Rowland Hill in 1837 , and carried into effect, in spite of the opposition of the Post Office officials, in 1840 . The establishment of the penny post, together with the novel rapidity and regularity of the service rendered possible by railway extension, is in itself a reform which in earlier ages would have sufficed to render a reign illustrious. It has been supplemented by a telegraph system which as far transcends the penny post as that surpasses the clumsy and costly system of the last century; and the telegraph is in turn yielding the palm to the telephone, in the use of which, however, this country, owing to the obstructiveness of the Post Office, is far behind America and some Continental States.

"The maritime supremacy of this country was fully established long before the accession of Victoria, and the marine steam-engine was familiar long before the locomotive. Patents for screw propellers were even taken out a century ago, although they were not successfully applied until 1837, when Ericsson attained a speed of ten miles an hour. In the following year the Great Western performed what was then the extraordinary feat of making the passage from Bristol to New York in eighteen days. Considerable success had thus been attained before the present reign in the application of steam to marine transport, but the advance that has since been made is not less remarkable than the improvement in land transport. The voyage to New York is now performed in six days, and ships are actually sailing between Liverpool and the Isle of Man at a speed equivalent to doing the $\mathrm{New}$ York passage in five. But the real measure of the revolution that has taken place must be sought in the supersession of sailing vessels by steamers for all the purposes of commerce, and the consequent multiplication of the resources of industry. At the beginning of the reign the tonnage of British steam-ships was considerably under 100,000 tons. It is now about $4,000,000$. But just as the immense growth of railways has not prevented a large increase in the traffic of the canals, so has the increase of steam-shipping left room for an addition of 50 per cent. to the tonnage of British sailing-vessels. The increase of steam-tonnage taken alone gives but an imperfect idea of the progress that has been made. For by continual improvements in marine engines each ton of shipping is moved at a greatly increased rate and a greatly diminished cost; while, as regards a very large and important portion of our trade, the opening of the Suez Canal, to which we supply fourfifths of its traffic, has still further economized time and labour. In this connexion by far the most important 
achievement of recent years is the opening of the Canadian Pacific Railway, and the establishment of a line of steamers connecting its western terminus with India, China, and Japan. We thusgain a shortened route to the East, passing entirely over great ocean highways and British territory instead of through a land-locked sea and a narrow gut which accident or design may at any moment render impassable. In view of the expansion of commerce during the last half-century, and of the immense undeveloped resources of Canada, it would be rash to set any limits to the future possibilities of this great Imperial highway.

"The universal acceleration of locomotion and transit is the most extended and general application of science to the great modern purpose of economizing labour and time. Every department of industry can, however, show special applications for effecting the same result."

\section{ATLANTIC WEATHER CHARTS.}

$\mathrm{T}$ $\mathrm{E}$ Meteorological Council has recently issued the second part of the Synchronous Weather Charts for the North Atlantic and the adjacent continents, the folio just published embracing two charts for each day from November 8, I882, to February 14, I883. The first part was noticed in NATURE, vol. xxxv. p. 469, when we gave a somewhat detailed explanation of the charts and the observations upon which they were based. The second part embraces a very large portion of an English winter, and the conditions pictured over the Atlantic show that the weather over that ocean in winter is far more disturbed than it is during the summer months. The barometer in the winter ranges both higher and lower, and the changes of pressure are much more rapid and considerable. The movements of the travelling distarbances are also accelerated, and keep in a much lower latitude, the British Islands coming frequently under their full influence after they have passed over the warm and moist air of the North Atlantic. In the summer the barometer is above 30 inches over the greater part of the ocean, but the highest readings seldom exceed $30^{\circ} 3$ inches, whilst the areas of low pressure, the readings at the centre of which are seldom especially low, ranging for the most part from $29^{\circ} 2$ to $29^{\circ} 5$, skirt to the north of the high-pressure area, and pass as a rule well to the northward of the United Kingdom. At times these low-pressure areas scarcely influence our weather. At other times, when from some cause the high-pressure area is situated in rather a lower latitude than usual, the low centres will have a more southerly route in their passage from west to east, and will occasion disturbed weather over our islands, but for want of sufficient difference of barometric pressure will but very seldom materially augment the strength of the wind. If, however, this southerly track of the disturbances is maintained for any length of time in the summer, it will have a very marked effect upon our weather, occasioning frequent and heavy rains; it was this which caused the entire failure of real summer weather in 1879 . The winter charts show that the barometer often ranges as high as $30^{\circ} 5,30 \%$, and $30 \%$ in Mid-Atlantic, whilst on the adjacent continents such readings are common, and in North America much higher readings occur-on February i the mercury reached $3 I^{\circ} I$ inches. The charts do not extend to Siberia, but it is notorious that excessively high readings are commonly experienced there during the winter months. The low-pressure areas which are principally limited to the ocean, and almost solely to the northern latitudes, frequently have the barometer at the centre below 29 inches, and occasionally below 28 inches. With these differences of barometric pressure there is ample material for the development and maintenance of storm systems ; and the most cursory examination of the charts shows to how great an extent storm after storm rages almost daily in one part or another of the Atlantic, and frequently several storm areas exist at one and the same time. This second series of charts illustrates in the most unmistakable manner the behaviour of storms over the Atlantic: many a disturbance can be traced in its pro. gress for days together. On November I3 a storm area was passing over the north of France, and was occasioning strong easterly gales in the south of England and the English Channel. This disturbance can be traced back day by day until November 3 , when it was in the vicinity of the West Indies, where it was apparently bred. The severe storm which was blowing over the British Islands on November 19 was apparently formed over central North America on November 9, and, after travelling slowly over the Lake District, left the Gulf of St. Lawrence on November 14, and followed a north-easterly track, but, after passing over the south of Greenland, it took a more southerly course, the centre subsequently passing between Iceland and Scotland. A fairly good specimen of storm development is shown on the charts of February 7 and 8: on the 7 th, a bend is shown in the isobars of $29^{\circ} \circ$ and $29^{\circ}$ I at about 300 or 400 miles to the west of Ireland, and this on the following day becomes a closed area with its complete wind circulation; the disturbance, however, dies out again on the 9 th. A feature of very special interest in the charts is the size of some of the disturbances: this stands out clearly from the graphic manner of representation. There are many instances of a gale blowing simultaneously in America and Europe, due t the same storm area, and in these cases the area of lowbarometer readings usually occupies the whole of the northern part of the Atlantic, whilst over the land, both in Europe and America, the barometric pressure ranges very high. On January 23 , as the result of a single lowpressure area, a gale was blowing in Hudson's Bay, Labrador, and Newfoundland, and completely across the Atlantic to the North Sea and the north of Norway, the diameter of the area over which the wind was blowing with gale force, being as much as 3800 miles (nautical); the centre of the storm was situated off the south-west coast of Greenland, where the barometer was reading 28.2 inches, whilst in America and Europe the baromete: reached 30.8 inches. An almost equally large disturb ance is shown on February Io, the gale force extending quite across the Atlantic from Labrador and the Gulf of St. Lawrence to the Gulf of Bothnia, the diameter of the gale area being fully 3000 miles.

The equatorial doldrum is shown to be of less extent than the general charts which have been deduced from averages would lead one to suppose, and very frequently the north-east and south-east trades almost meet. Between longitudes $20^{\circ}$ and $30^{\circ} \mathrm{W}$., the position at which the trades meet in November is about $5^{\circ} \mathrm{N}$., in December about $3^{\circ} \mathrm{N}$., whilst in January and the early part of February the south-east trade only just blows north of the equator, and the doldrum is probably at this time at its mos? southern limit. The north-east trade is far more regulat on the eastern side of the Atlantic than in mid-ocean os on the western side, and this is fully accounted for by the fact that the wind blows round the Atlantic high-pressure area in agreement with the ordinary anticyclonic circulation, so that on the eastern side of this high pressure which is also, as a rule, the eastern side of the Atlantic, the wind is northerly, whereas to the westward of this area of high barometer readings the winds are frequently from the southward. The northern margin of the trade varies considerably, and is almost entirely dependent on the position of the area of high barometer situated over the Atlantic; when this area is well to the northward the northerly winds hold from the chops of the Channel down the coast of Africa to about $5^{\circ} \mathrm{N}$., so that a vessel may leave England and keep a steady northerly and northeasterly wind until close to the equator.

The winter charts also show that the differences of temperature are much larger over the Atlantic than they 